\title{
Evaluation Of The Training Program For The FORKI DKI Jakarta Pelatda Athletes Towards The 2016 KASAD Cup 2016 Jambi
}

\author{
Aneke M Y Enoch \\ Physical Education, Universitas Negeri Jakarta, Jl. R.Mangun Muka Raya No.11, East Jakarta \\ City, DKI Jakarta 13220, Indonesia \\ Email: aneke88@gmail.com
}

\begin{abstract}
To improve an organization, good management is needed because it cannot be denied that an organization will succeed if it is appropriately challenged. The success of an achievement sports organization is always linked to how far the organization produces sportsmanship. Educational sports management is implemented in the school environment, formal and nonformal education, and universities. Recreational sports management is applied to community sports organizations. The method and design used in this research are descriptive. This research is evaluative research using the CIPP model (Context, Input, Process, Product) proposed by Stufflebeam. Awareness, The position of athletes for achievement, is still categorized as lacking; the suitability of the training program is still categorized as lacking or even lacking. It still has to be addressed according to the needs and development of karate today. Based on observations, interviews, and strengthened documentation during the study, obtained results: FORKI Jakarta always sends nationally educated athletes even though they often experience failure due to the training program not fully fulfilled from infrastructure, understanding of programs, etc.
\end{abstract}

Keyword: evaluation, FORKI

(C) 2021 Aneke M Y Enoch

Under the license CC BY-SA 4.0

\section{INTRODUCTION}

Each country will generally have an activity related to national sports, in Indonesia also has national sports activities which are typically held every year, national championships, the Minister of Home Affairs, Minister of Education and Culture, the Minister of National Education, some events are held biennially; namely, the KASAD Cup, and the multi even National Sports Week (PON), which is held every four years, is a very prestigious sporting event and is highly coveted by athletes, coaches, administrators and even the prestige of a governor. In a big event like PON, the role of all levels of society will be needed. From government to community. The youth and sports department hold the part of the government here. 
One of its roles is "Increasing youth participation in the development and improvement of sports achievement (Sarangan, 2014) (Bangun, 2016). A significant event can be successfully carried out if the activity gets maximum support from both the local government and the community.

In the life of society, nation, and state, sports management are not only carried out by one institution individually without any related relationships from various parties or other institutions (Kurnia, 2018), so that a kind of inter-institutional coordination network is needed so that synchronization between sports institutions runs optimally and the results have an impact on future athlete performance. A country will be vital if the nation is healthy (Galih, 2017). This is not just a slogan but a fact. Indonesia is one of the countries that can be reckoned with in Asia, especially Southeast Asia, one of the sports that is Indonesia's mainstay is karate. Before 1997 at the XIX Sea Games in Jakarta, PB FORKI presented 14 gold medals. After 1997, Indonesia experienced a crisis. economic activities will automatically affect sports activities because it is impossible for conditions like this to do much for sports activities that require a large budget. The prolonged crisis has an impact on sporting events, including the Sea Games, Asian Games. Throughout 1997-2009 Indonesia's position was always under Thailand, Malaysia, and even Vietnam.

However, in 2011 Indonesia reclaimed the overall champion crown in JakartaPalembang, but in 2013 again, Indonesia experienced losing the overall champion crown in Myanmar. At the Sea Games event in 2011, Indonesia presented ten gold medals, and four gold medals were presented by the DKI Jakarta FORKI karate athletes Plenty Enoch (Individual Kata), Dewi P (Team Kata), Fitri (Kumite -53 kg), Cristo (Men's Kumite). At the 2013 Sea Games, Indonesia in the karate sport could not present a gold medal for Indonesia.

The results of the evaluation of sports programs show that one of the factors that hinder coaching is the performance of organizational Management that has not been optimal; there are still various problems such as the selection system that is not good, lack of awareness of the administrators of responsibility so that they work slowly, coordination between individuals that is not optimal, the organization of tasks is not regular and so on. Moreover, factors in the field also play a role. The purpose of the evaluation is as stated by Wahyu Hidayat "Evaluating is carried out to find out 
and improve on strengths, weaknesses, opportunities, challenges, and threats (Hidayat \& Rahayu, 2015).

With the current conditions, the DKI Jakarta FORKI administrators are trying to improve themselves. They are trying hard to improve the performance of the athletes and the quality of the coaches and referees. To overcome the coaching problems that occur, it is not enough to hope for talent, enthusiasm, and motivation to win something, but there must be an improvement. Guidance must be in line with Law of the Republic of Indonesia Number 3 of 2005, namely:

The national sports system in all aspects of sports is interrelated in a planned, systematic, integrated, and sustainable manner as a single unit which includes regulation, education, training, Management, guidance, development, and supervision to achieve national sports goals. The Central and Regional Governments must conduct sports coaching and development following their authorities and responsibilities (Pardomuan, 2014) (Ramadhan et al., 2020).

Because it is realized to improve an organization requires good Management, because it cannot be denied that an organization will succeed if it is appropriately managed. The success of an achievement sports organization is always associated with how far the organization produces the achievements of the athletes (Mirnawati et al., 2018). Theoretically, it can be said that an achievement sports organization that can carry out its management functions well can be expected to produce exemplary achievements as well. Problems in Management include, as stated as follows: Barriers to the implementation of Management found several factors that can be referred to as obstacles to coaching in the framework of Coaching Management, including the lack or weakness of Facilities and Infrastructure, funds, and trainers. The inhibiting factor for coaching management is that respondents still recognize coaching Management as adding to the cost burden of athletes (Haryadi et al., 2017).

So it is not surprising that the leaders and administrators constantly strive to improve the existing conditions because the achievements achieved now must be better than yesterday's achievements, and future achievements must be better than current achievements so that it can be said that there is an increase in achievement. DKI Jakarta FORKI administrators are improving themselves by being more selective in determining the coaches and administrators who are chosen to carry out their 
duties and responsibilities in improving performance; DKI Jakarta FORKI does not work alone are also fully assisted by KONI Pengprov DKI Jakarta. The best for the Management, in this case, is that the trainer must be able to make programs that are well managed, especially programs in good coaching and Management in the DKI Jakarta FORKI organization assisted by the DKI Jakarta Provincial KONI. In the research results, it is hoped that the focus of the problem will be identified, which will later be the focus of the research. The focus of this research is related to context, input, process, product.

\section{METHODS}

The method and design used in this research is the descriptive method (Ramadan \& Juniarti, 2020). The descriptive research method can be interpreted as a problem-solving procedure investigated with problem-solving approaches investigated by describing the research subject (a person, institution, community, etc.), at present based on the facts that appear (Surajiyo, 2010). This research is evaluative research using the CIPP (Context, Input, Process, Product) model proposed by Stufflebeam. The use of the CIPP model was chosen because this model is believed to identify all components regarding the implementation of training program management starting from preparation to results; the details obtained are part of the implementation of this evaluation.

The population in this study is all karate prepared for national events, both the junior team which will be included in the national competition, the Mendikbud Cup, the Mendagri Cup, Popnas, and joined with the DKI FORKI Pelatda team. The sample is part of the population that is considered representative of several existing populations. According to Hadi, the sample is part of the population. The sampling technique in this study used a purposive technique, namely by selecting people who were considered to know about the focus of the problem, such as parties related to decision making, athletes, and coaches for the DKI Jakarta FORKI regional training athlete preparation program.

The research instrument is a written guide about interviews or observations or a list of questions prepared to obtain information from respondents. The data collection instrument in this study was carried out with various techniques, namely: interview guides, literature studies, surveys. 


\section{RESULTS AND DISCUSSION}

The results of interviews and documentation related to the coach's awareness of the importance of the training program, it can be concluded that the understanding of the coaches and administrators in fostering Karate at FORKI Jakarta only wants maximum results without any attention or assistance in overcoming athlete problems so far at national events. The results of direct interviews and documentation explaining the evaluation of the input for coaching the achievement of FORKI Jakarta found that the qualifications of the FORKI Jakarta athletes had met the requirements. Awareness, The athletes' position for achievement, is still categorized as lacking; the suitability of the training program is still classified as lacking or even very lacking. It still has to be addressed according to the current needs and developments of karate.

Based on the results of direct interviews, observations, and documentation during the researchers conducting research, the results obtained are: (1) The implementation of the training program is following the plan. (2) Athletes' motivation when exercising is good. Motivation to practice can be seen from the average athlete being very disciplined in training, but not all athletes understand the target achievement. Based on the results of observations, strengthened by direct interviews and documentation during the research, it can be concluded that the quality of the supervisor's control over the performance development of FORKI Jakarta is inferior; all the coaches want to ask for achievements without knowing the process to get what achievements need to be addressed, it seems that the training program is challenging to implement. Support, both material and non-material, all athletes did not feel at all.

Coaching karate achievements, coaches and athletes must have insight into the importance of an exercise program that will be carried out. Many coaches and athletes still do not have unique insight into training programs, mainly because there are no nationally licensed trainers who can understand the athletes being fostered and the lack of coaches participating in seminars, training, counseling, and upgrading of coaches every year. Based on the results of interviews and documentation related to the awareness of the coaches and coaches about the 
importance of the training program, it can be concluded that the understanding of the coaches in fostering karate achievement coaching athletes in Jakarta only wants maximum results without any attention or assistance to overcome athlete problems so far due to physical factors. The trainers only run a makeshift training program at national events without knowing the training program that continues to develop or is updated.

Based on the results of interviews and documentation related to the feasibility or qualifications of trainers and coaches, it can be concluded that there are no nationally licensed trainers. The current regional licenses owned by trainers have been too long. There has been no renewal of understanding about the karate training program by attending several seminars or trainer training. Karate to know the development of modern karate. Moreover, to become a coach, you must have a little insight to develop an institution. However, the fact is that there is no understanding about the institution being fostered, which only asks the coach to produce the best possible performance based on the results of interviews and documentation regarding athletes' awareness of the importance of training programs for achievement, it was found that in the training process athletes were less motivated in carrying out the exercises given by the coach due to the lack of variety of coaches in shaping the training atmosphere and the lack of prior understanding to athletes that it was vital for achievement.

\section{CONCLUSION}

Based on the results of the research that has been stated, several conclusions can be drawn as follows;

1. Context

a. The foundation in implementing stakeholders regarding athlete development at PB FORKI and FORKI Jakarta already has a sufficient foundation, although it still has to be considered.

b. Stakeholders' views and understanding of the athlete development program at PB FORKI and FORKI Jakarta have been categorized as good; besides that, they still need significant improvements.

c. The objectives of program activities in PB FORKI and FORKI Jakarta and their relevance to regional and national achievements have been seen from 
each of them, which has given birth to achievements at the regional level, but none at the national level.

2. Input

a. Availability of planning for development programs in PB FORKI and FORKI Jakarta, but all the plans did not match what was seen in the field during implementation.

b. Availability of qualified trainers to support the development of athletes in PB FORKI and FORKI Jakarta who are already well adapted to FORKI guidelines.

c. The quality of athletes involved in coaching athletes is quite good, seeing from the achievements that there has been a different level division for each athlete.

d. The availability of adequate facilities and infrastructure to support the training program is quite good, although it has not yet adjusted the FORKI guidelines.

e. Management and organizational support in preparing performance development training programs at PB FORKI and FORKI Jakarta for athlete coaches are minimal. At the same time, local government officials at PB FORKI and FORKI Jakarta only leave it entirely to managers without any assistance.

3. Process

a. Preparation of implementing the achievement development program at PB FORKI and FORKI Jakarta in writing, both short, medium, and long-term plans.

b. According to established guidelines, the implementation of an athletic development program consists of physical components, namely endurance, strength, flexibility, speed, coordination, and power.

c. Supervision of achievement development programs at PB FORKI and FORKI Jakarta is good, although good coaches still need to understand the importance of developing good athletes.

4. Product

a. The achievement of the quality and quantity of athletes after participating in the coaching of athletes at PB FORKI and FORKI Jakarta is sufficient for the 
regional level, as can be seen from the achievements and results of the evaluation data of the respective coaches. However, they still need to be addressed to compete on the national level.

b. The increase in achievement after participating in sports coaching is already good; it is seen from the athlete's achievement evaluation data.

\section{REFERENCES}

Bangun, S. Y. (2016). Peran Pendidikan Jasmani dan Olahraga pada Lembaga Pendidikan di Indonesia. Publikasi Pendidikan. https://doi.org/10.26858/publikan.v6i3.2270

Galih, Y. S. (2017). Kewajiban Negara Melindungi Anak Bangsa. Jurnal IImiah Galuh Justisi, 5(1). https://doi.org/10.25157/jigj.v5i1.249

Haryadi, W. M., Pratidina, G., \& Seran, M. Y. (2017). Studi Manajemen Pembinaan Olahraga Sepak Bola di Klub Persatuan Sepak Bola Kota Bogor oleh Kantor Pemuda dan Olahraga Kota Bogor. JURNAL GOVERNANSI. https://doi.org/10.30997/jgs.v2i1.208

Hidayat, W., \& Rahayu, S. (2015). Evaluasi Program Pembinaan Prestasi Sepakbola Klub Persibas Banyumas. JSSF : Journal of Sport Sciences and Fitness, 4(2), 10-15.

Kurnia, M. (2018). Peluang Industri Olahraga di Indonesia. Peluang Industri Olahraga Di Indonesia, 1(1).

Mirnawati, Tawai, A., \& Idrus, S. H. (2018). Pelaksanaan Fungsi Manajemen Dalam Menunjang Tertib Administrasi Pada Dinas Pendidikan Kepemudaan Dan Olahraga Kota Kendari. Jurnal Kebijakan Publik.

Pardomuan, R. (2014). Mengidentifikasi Atlet Muda Berbakat Menggunakan Uji Keterampilan Bola Basket. Bravo's Jurnal, 2(3).

Ramadhan, M. G., Ma'mun, A., \& Mahendra, A. (2020). Implementasi Kebijakan Olahraga Pendidikan sebagai Upaya Pembangunan Melalui Olahraga Berdasarkan Undang-Undang Sistem Keolahragaan Nasional. Jurnal Terapan IImu Keolahragaan, 5(1). https://doi.org/10.17509/jtikor.v5i1.23824

Ramadan, G., \& Juniarti, Y. (2020) Metode penelitian: pendekatan kuantitatif, 
kualitatif dan R\&D. CV Sadari Press

Sarangan, M. A. (2014). Peran Dinas Pemuda dan Olahraga dalam Meningkatkan Prestasi Atlet Kempo di Provinsi Kalimantan Timur. EJournal IImu Pemerintahan, 2(4), 3222-3231.

Surajiyo. (2010). Filsafat IImu dan Perkembangannya di Indonesia. Bumi Aksara. 